\title{
No. X.-PTEROPODA AND HETEROPODA.
}

\author{
By Dr. J. J. Tesch, Helder, Holland.
}

\section{(Plates 12-14.)}

(Communicated by Prof. J. Stanley Gardiner, M.A., F.R.S., F.L.S.)

Read 21st April, 1910.

\section{PTEROPODA.}

The Pteropoda, collected by the Percy Sladen Trust Expedition in the Indian Ocean, were few in species. The Gymnosomata indeed were not represented. This may be attributed to two principal causes, viz. (1) the region explored lay wholly in warm tropical waters, and did not extend to areas of cooler temperatures, so that a great diversity of forms, as Meisenheimer* has particularly pointed out, could not be expected ; and (2) only few hauls were made in the open sea, the characteristic dwelling-place of the Pteropoda, as the members of the expedition devoted themselves chiefly to exploration in the neighbourhood of reefs.

The area of the Indian ocean, in which the Sealark worked, was also explored to some degree by the Valdivia Expedition. We are thus enabled to compare the results of the two expeditions. It is a remarkable fact that not only the Gymnosomata Clionopsis grandis, Notobranchaa valdivice and Halopsyche gaudichaudi were not caught by the Sealark, but also that Peraclis moluccensis, which was repeatedly found by the German naturalists, did not occur among the spoils, submitted to me, from the same regions. On the other hand I feel justified in describing a species of Desmopterus as new.

\section{ENUMERATION OF THE SPECIES.}

\section{A. EUTHECOSOMATA.}

\section{Limacinidæ.}

Limacina Cuvier.

\section{Limacina inflata (d'Orbigny).}

Stat. P (124†), Q (2), Chagos Archipelago ; u (3), v (1), Farquhar.

* Wissenschaftliche Ergebnisse der deutschen Tiefsee-Expedition auf dem Dampfer "Valdivia," 1898-1899, Pteropoda, 1905.

+ The figures in brackets indicate the number of specimens. A full list of the stations will be found in Trans. Linn. Soc. Ser. 2. Zool. vol. xii. pp. 170-4; they are iudicated by letters. 
2. Limacina trochiformis (d'Orbigny).

Stat. P. (3), Chagos Archipelago; n (1), Saya de Malha Bank; dd (1), Amirante Group.

3. Limacina bulimoides (d'Orbigny).

Stat. P (13), Chagos Archipelago.

Peraclis* Forbes.

4. Peraclis reticulata (d'Orbigny).

Stat. u (1), Farquhar.

\section{Cavoliniidæ.}

5. Creseis virgula Rang.

Creseis.

Stat. A (1), F (2), N. of Chagos Archipelago ; d (1), Mauritius ; e (1), MauritiusCargados Carajos; dd (13), nn (1), Amirante Group.

6. Creseis acicula Rang.

Stat. P (1), Chagos Archipelago ; u (3), Farquhar ; x (3), Providence ; kk (6), nn (4), Amirante Group.

\section{Styliola Lesueur.}

7. Styliola subula (Quoy et Gaimard).

Stat. e (1), Mauritius; n (1), N. of N. Saya de Malha Bank.

\section{Hyalocylix Fol.}

8. Hyalocylix striata (Rang).

Stat. A (1), B (2), N. of Chagos Archipelago; H (1), L (4), Chagos Archipelago ; e (1), Mauritius-Cargados Carajos; n (8), N. of N. Saya de Malha Bank ; v (1), Farquhar; kk (4), mm (1), Amirante Group.

\section{Cuvierina Boas.}

\section{Cuvierina columnella (Rang).}

Stat. N (2), Chagos Archipelago ; mm (1), nn (1), Amirante Group.

* With regard to the recent paper of Meisenheimer (Die Pteropoden der deutschen Südpolar-Expedition, 1901-1903, 1906) in which a chapter occurs on the genus Peraclis, I am doubtful about the specific distinctness of his species $P$. apicifulva and another form, described almost simultaneously, by Pelseneer, P. brevispira (Biscayan Plankton collected during a cruise of H.M.S. “Research," 1900, Part vil., Mollusca (excluding Cephalopoda), Trans. Linn. Soc. London, vol. x. Part 5, February 1906). The general shape of the shell is somewhat the same, differing only in the fact that in $P$. apicifulva there are 4 coils, whereas in Pelseneer's species there are only $2 \frac{1}{2}$. The opercula agree closely, especially in the striated portions around the central coils of the nucleus. The small rim-like elevations, perpendicular to the suture on the last whorl, in $P$. apicifulva occur also in $P$. brevispira in the form of "petites lamelles rayonnantes, surtout visibles au dernier tour." Finally the sculpture seems to be alike in both species. 
Clio Linné.

10. Clio pyramidata Linné.

Stat. C (8), N. of Chagos Archipelago; N (1), P (3), Chagos Archipelago; c (3), d (3), Mauritius; e (1), Mauritius-Cargados Carajos; n (5), Saya de Malha Bank; q (3), Farquhar ; $y$ (1), Providence; aa (4), N. of Providence; ee (1), kk (1), ll (10), mm (7), nn (13), Amirante Group. Dredging Stat. C 20 (3), Saya de Malha Bank.

11. Clio cuspidata (Bosc).

Stat. C (7), N. of Chagos Archipelago; N (1), Chagos Archipelago. Dredging Stat. C 20 (2), Saya de Malha Bank.

Cavolinia Abildgaard.

12. Cavolinia tridentata* (Forskål).

Stat. e (1), Mauritius-Cargados Carajos; x (3), Providence ; kk (2), Amirante Group.

13. Cavolinia longirostris (Lesueur).

Stat. F (2), N. of Chagos Archipelago ; x (2), Providence; dd (1), mm (3), nn (1), Amirante Group.

14. Cavolinia uncinata (Rang).

Stat. C (1), N. of Chagos Archipelago ; ee (2, 1 empty), Amirante Group. Dredging Stat. C 16 (2, empty), C 20 (4, empty), Saya de Malha Bank.

15. Cavolinia gibbosa (Rang).

Dredging Stat. C 16 (3, empty), C 20 (4, empty), Saya de Malha Bank.

16. Cavolinia globulosa (Rang).

Stat. C (2), N. of Chagos Archipelago; aa (1†), N. of Providence; ll (10), mm (1), Amirante Group. Dredging Stat. C 16 (2, empty), Saya de Malha Bank.

17. Cavolinia inflexa (Lesueur).

Stat. p (1), Farquhar.

\section{Diacria Gray.}

18. Diacria trispinosa (Lesueur).

Stat. C (5), N. of Chagos Archipelago; nn (1), Amirante Group. Dredging Stat. C 16 (3, empty), Saya de Malha Bank.

19. Diacria quadridentata (Lesueur).

Stat. u (3+), Farquhar; mm (2) Amirante Group. Dredging Stat. C 16 (7, empty), Saya de Malha Bank.

* All specimens were in a young stage (Pleuropus longifilis Troschel).

$\dagger$ This specimen was also in a young stage (Hyalca rotundata Boas).

$\ddagger$ All specimens were young (Cleodora pygmeea Boas); it is, however, not quite certain whether this form really should be referred to Liacria quadridentata. 


\title{
B. PSEUDOTHECOSOMATA.
}

\section{Cymbuliidæ.}

20. Cymbulia sp.

\author{
Cymbulia Péron et Lesueur.
}

Stat. B (3), C (47), F (4), N. of Chagos Archipelago ; L (1), W. of Chagos Archipelago ; d (2), Mauritius ; 1 (1), Nazareth Bank ; p (1), q (2), Farquhar ; x (1), Providence ; aa (2), bb (2), N. of Providence; nn (1), Amirante Group.

At many stations representatives of the genus Cymbulia, apparently mostly young forms, were obtained. They all possessed in a more or less advanced stage of growth a ventral lobe to the fin, and the larger specimens seemed to agree in all essential features with Cymbulia siboga Tesch, which has already been recorded by Meisenheimer* from the Chagos Archipelago and from the Seychelles. Unfortunately none of my specimens possessed a concha; a clear determination was not therefore possible.

\section{Desmopterus Chun.}

21. Desmopterus papilio (Chun).

Stat. A (10), B (3), F (4), N. of Chagos Archipelago; Q (1), Chagos Archipelago; x (1), Providence; kk (2), Amirante Group.

The specimens had lost all pigment; the tentacular process on the fins was always more or less broken off.

\section{Desmopterus gardineri, n. sp. (Plate 12, figs. 1, 2.)}

Stat. B (1), N. of Chagos Archipelago.

The general form of the body is about the same as in D. papilio, on the whole cylindrical; proximally, however, it becomes gradually more slender and forms a short proboscis, almost perpendicular to the axis of the trunk; distally, it bears a ventral groove, composed of large glandular cells. The very thin, transparent integument is provided with a great many unicellular, but rather large, roundish glands. Similar glands have also been described by Meisenheimer $\dagger$ in $D$. papilio, though they are here much smaller. The musculature of the fins forms the most prominent character of the new species; this musculature is composed of rather broad bands, all distinctly separated, and running in two main directions, the one at right angles to the other. Distally a few bands only of the horizontal system, after passing into the inner ventral lobe of the fin, take an opposite direction and form part of the vertical bands. The whole system is very much like that of D. papilio except for the much broader and clearly separated bands; there accordingly exists in the musculature of the fins a similar difference like that of Cymbulia compared with Corolla. The knob-like, small agglomerations of glands, described by Meisenheimer on the fins of $D$. papilio I also found in $D$. gardineri.

The only specimen obtained was in the $\hat{\delta}$ stage, as is shown by the presence of a distinct penis, invaginated at the right side of the head (fig. 2, $p$ ). The gonad (fig. 1, gon)

* Pteropoden der deutschen Tiefsee-Expedition, p. 38. † l.c. p. 209, Pl. xıv. figs. $8,13$.

‡.c. p. 209, Pl. xıv. fig. 6 . 
occupies the hinder part and a great deal of the left side of the visceral mass. At the right side is situated an accessory gland (fig. 1, acc. $g l$ ), the rather advanced stage of development of which shows, according to Meisenheimer's investigations*, that the specimen will soon pass into the $f$ sexual stage.

As to the other organs, they are quite like those of the previously described species. On the head, close to the buccal mass (fig. $2, \mathrm{bm}$ ) two small tentacles are visible $(t)$ and a pair of salivary glands. The very short œsophagus opens directly into a very wide and large, thin-walled stomach (fig. 1, st), from the right upper corner of which issues a thin intestine (int), which passes over to the left side and opens distally at the ventral margin of the hinder glandular groove. The heart and kidney are situated distally from the accessory sexual gland, the heart with its ventricle directed forwards.

Diameter across the fins $5 \mathrm{~mm}$.

I have dedicated this species to its discoverer, Prof. J. Stanley Gardiner.

\section{LIST OF THE STATIONS, FROM WHICH PTEROPODS HAVE BEEN RECORDED.}

\section{A. Plankton Stations.}

Stat. A, May 16, 2.58-3.43 P.м. $\quad 3^{\circ} 31^{\prime}$ S., $72^{\circ} 27^{\prime}$ E.

25-0 fms. Creseis virgula (1), Desmopterus papitio (10).

125-0 fms. Hyalocylix striata (1).

Stat. B, May 17, 2.20-2.55 P.м. $4^{\circ} 16^{\prime}$ S., $71^{\circ} 53^{\prime}$ E.

75-0 fms. Cymbulia sp. (1), Desmopterus papilio (1).

125-0 fms. Hyalocylix striata (2), Cymbulia sp. (2), Desmopterus papilio (2), Desmopterus gardineri (1).

Stat. C, May 17, 3.30-6.30 Р.м. Same position.

1200-0 fms. Clio cuspidata (7), Clio pyramidata (8), Cavolinia uncinata (1), Cavolinia globulosa (2), Diacria trispinosa (5), Cymbulia sp. (47).

Stat. F, May 18, 2.10-3.10 A.M. Same position.

Surface. Creseis virgula (1), Desmopterus papilio (4).

25-0 fms. Creseis virgula (1), Cavolinia longirostris (2), Cymbulia sp. (4).

Stat. H, May 18, 3.58-5.40 P.м. Same position.

Surface. Hyalocylix striata (1).

Stat. L, June 6, 8.40-9.40 P.M. N.E. Gt Chagos Bank.

75-0 fms. Hyalocylix striata (1).

125-0 fms. Hyalocylix striata (3), Cymbulia sp. (1).

Stat. N, June 30, 12-12.40 P.M. Peros Atoll.

600-0 fms. Clio cuspidata (1), Clio pyramidata (1), Cuvierina columnella (2).

* l.c. pp. $216,217, \mathrm{Pl}, \mathrm{xv}$.

SECOND SERIES-ZOOLOGY, VOL. XIV. 
Stat. P, June 30-July 1, 6.30 P.м.-6.30 A.M. Salomon Atoll. 10-0 fms. Limacina inflata (124), Limacina trochiformis (3), Limacina bulimoides (13), Creseis acicula (1), Clio pyramidata (3).

Stat. Q, July 4-5, 7.15 P.м. -7.15 A.м. Same position.

Surface. Limacina inflata (2), Desmopterus papilio (1).

Stat. c, Aug. 22, 4.40-5.20 Р.м. Mauritius. 250-0 fins. Styliola subula (1), Clio pyramidata (3).

Stat. d, Aug. 22-23, 7 P.м. - 5 A.м. Same position.

Surface. Creseis virgula (1), Clio pyramidata (3), Cymbulia sp. (2).

Stat. e, Aug. $25,1.30-3$ P.M. $18^{\circ} 9^{\prime}$ S., $58^{\circ} 21^{\prime}$ E.

150-0 fms. Cavolinia tridentata (2, "Pleuropus longifilis").

200-0 fms. Creseis virgula (1).

300-0 fms. Creseis virgula (3), Hyalocylix striata (1).

400-0 fims. Clio pyramidata (2).

Stat. 1, Sept. 2, 11.45 A.M. -12.30 P.м. $14^{\circ} 38^{\prime}$ S., $60^{\circ} 1^{\prime}$ E.

250-0 fms. Cymbulia sp. (1).

Stat. n, Sept. 8. N. of N. Saya de Malha Bank.

Surface. Limacina trockiformis (1), Styliola subula (1), Hyalocylix striata (8), Clio pyramidata (5).

Stat. p, Sept. $27,7-9.30$ A.м. $10^{\circ} 27^{\prime}$ S., $51^{\circ} 17^{\prime}$ E.

300-0 fms. Cavolinia inflexa (1), Cymbulia sp. (1).

Stat. q, Sept. 27, 7-9.30 A.м. Same position.

1000-0 fms. Clio pyramidata (3), Cymbulia sp. (2).

Stat. u, Sept. $29-30,7$ P.M. -7 A.M. Farquhar.

Surface. Limacina inflata (3), Peraclis reticulata (1), Creseis acicula (3), Diacria quadridentata (3, "Cleodora pygmaa").

Stat. v, Sept. 30 -Oct. 1, 7 P.м. - 5 A.M. Same position.

Surface. Limacina inflata (1), Hyalocylix striata (1).

Stat. x, Oct. 2-3, 8 P.м. -6 A.м. Providence.

Surface. Creseis acicula (3), Cavolinia tridentata (3, "Pleuropus longifilis"), Cavolinia longirostris (2), Cymbulia sp. (1), Desmopterus papilio (1).

Stat. y, Oct. $4-5,8$ P.м.-6 A.M. Same position.

Surface. Clio pyramidata (1).

Stat. aa, Oct. 6, 11.30 A.M. - 1.30 P.M. $8^{\circ} 16^{\prime}$ S., $51^{\circ} 26^{\prime}$ E.

900-0 fms. Clio pyramidata (4), Cavolinia globulosa (1, "Hyalca rotundata"), Cymbulia sp. (2).

Stat. bb, Oct. 6, 3-3.30 P.м. Same position. 140-0 fms. Cymbulia sp. (2). 
Stat. dd, Oct. 7, 4-5.30 р.м. Alphonse Island.

Surface. Limacina trochiformis (1), Creseis virgula (13), Cavolinia longirostris (1).

Stat. ee, Oct. 7-8, 9 р.м.-6 A.м. 10 miles S.E. of Alphonse Island.

Surface. Clio pyramidata (1), Cavolinia uncinata (2, 1 empty).

Stat. kk, Oct. 16, 8-9.30 A.м. Desroches Atoll.

50-0 fms. Hyalocylix striata (4).

100-0 fms. Hyalocylix striata (2), Desmopterus papilio (2).

150-0 fms. Creseis acicula (6), Hyalocylix striata (3).

300-0 fms. Clio pyramidata (1), Cavolinia tridentata (2, "Pleuropus longifilis").

Stat. 1l, Oct. 16, morning. Same position.

750-0 fms. Clio pyramidata (10), Cavolinia globulosa (10).

Stat. mm, Oct. 16, noon. Same position.

400-0 fms. Hyalocylix striata (1), Cuvierina columnella (1), Clio pyramidata

(7), Cavolinia longirostris (3), Cavolinia globulosa (1), Diacria quadridentata (2, 1 "Cleodora pygmaxa").

Stat. nn, Oct. 16, afternoon. Same position.

200-0 fms. Creseis virgula (1), Creseis acicula (4), Cuvierina columnella (1), Clio pyramidata (13), Cavolinia longirostris (1), Diacria trispinosa (1), Cymbulia sp. (1).

\section{B. Dredging Stations.}

Stat. C 16, Sept. 6. Saya de Malha Bank, 26 fms. Dredge triangular.

Diacria trispinosa (3), Diacria quadridentata (7), Cavolinia uncinata (2), Cavolinia globulosa (2), Cavolinia gibbosa (3). Only empty shells.

Stat. C 20, Sept. 7. Saya de Malha Bank, 331-500 fms. Trawl.

Clio pyramidata (3), Clio cuspidata (2), Cavolinia uncinata (4, empty), Cavolinia gibbosa (4, empty).

\section{VERTICAL DISTRIBUTION.}

As closing nets were used by the expedition only a few times, and no Pteropods were brought up by them, we are obliged to restrict ourselves to the results of the vertical hauls with open nets. Though for our special purpose their results are more vague and not quite so decisive as that of closing nets, they can be taken into account, as the exact hour of catch is nearly always given.

Now, as is well known, the Pteropoda make daily migrations in a vertical direction. At day-time they remain in deeper layers; as soon as it is getting dark, however, they rise to the surface. This seems especially to be the case with Euthecosomata and 
Pseudothecosomata*, although we can as yet give no sufficient explanation of these periodical migrations.

Looking over the foregoing list we may remark that the following species were caught at or near the surface down to $10 \mathrm{fms}$.

Limacina inflata, Stat. P, Q, u, v.

Limacina trochiformis, Stat. P, n, dd.

Limacina bulimoides, Stat. P.

Peraclis reticulata, Stat. u.

Creseis acicula, Stat. $\mathrm{P}, \mathrm{u}, \mathrm{x}$.

Creseis virgula, Stat. F, d, dd.

Styliola subula, Stat. n.

Hyalocylix striata, Stat. H, n, v.

Clio pyramidata, Stat. P, d, n, y, ee.

Cavolinia longirostris, Stat. $\mathrm{x}$, dd.

Cavolinia uncinata, Stat. ee.

Cavolinia tridentata ("Pleuropus longifilis"), Stat. x.

Cymbulia sp., Stat. d, x.

Desmopterus papilio, Stat. F, Q, x.

From this list, if compared with Prof. Stanley Gardiner's list, it may be seen that all these species with the exceptions of Creseis virgula, Hyalocylix striata and Cavolinia longirostris, were caught during the night $\dagger$; they thus afford another proof of the general rule mentioned above.

The bathymetric occurrence of Peraclis is worth mentioning: it was found during night at the surface. Formerly I noted a similar circumstance+, though here the exact hour could not be given. More than any other genus of the Thecosomata, Peraclis seems to belong to the mesoplankton. Miss Anne L. Massy§ mentions seven specimens of $P$. triacantha (Fischer) from a depth of $0-5$ fms, off the S.W. coast of Ireland; we have here another of the rare instances of the epiplanktonic occurrence of this genus.

\section{HETEROPODA.}

The number of species of this group of pelagic Mollusca is likewise small. By far the greater number of the specimens belong to the Atlantidæ or to Firoloida, other genera being very scantily represented, a result which seems to agree with that of the Siboga Expedition.

Though no new species were obtained, the material enables me to contribute somewhat to our knowledge of little-known species.

* See for instance Meisenheimer, l.c. pp. 97--99.

$\dagger$ The hour on which Stat. $\mathrm{n}$ was made is not recorded in the list of stations.

+ The Pteropoda of the Leyden Museum, Notes Leyden Museum, vol. xxix. p. 202.

$\S$ The Pteropoda and Heteropoda of the coasts of Ireland, Fisheries Ireland Sc. Inv. 1907, ii. (1909), p. 26 . 


\section{ENUMERATION OF THE SPECIES.}

\section{Atlantidæ.}

\section{Oxygyrus Benson.}

1. Oxygyrus rangi (Souleyet). (Plate 12, fig. 3.)

Stat. N (1), Chagos Archipelago.

The only specimen has been figured here in order to show the extension of the chalky part of the shell with the spiral undulating lines, which part is very distinctly separated (at the under side of the shell at least) from the horny part. The shell, with a maximum diameter of $1 \frac{1}{2} \mathrm{~mm}$. without the keel, represents a stage of growth, immediately following that figured by Macdonald*. As to further particulars I may refer to my former publications on this subject $†$.

\section{Protatlanta Tesch.}

\section{Protatlanta souleyeti (E. A. Smith).}

Stat. n (14), N. of N. Saya de Malha Bank.

Contrary to my former statementł about Souleyet's specimens, I may remark that the shell is quite chalky and not at all horny, as has been rightly pointed out by E. A. Smith§. This difference may possibly be ascribed to the very long conservation of Souleyet's specimens, though they looked quite well preserved. Except for this difference, I have nothing to add to my former investigations. All the specimens had lost their keel, which, as is well known, is very liable to be detached.

This is the first record of this species from the Indian Ocean, all former notes mentioning it as occurring in the Atlantic.

\section{Atranta Lesueur.}

3. Atlanta peroni Lesueur.

Stat. N (1), P (3), Chagos Archipelago ; q (2), u (1), Farquhar; hh (1), mm (1), Amirante Group.

\section{Atlanta lesueuri Souleyet.}

Stat. L (1), E. of Chagos Archipelago; n (21), N. of N. Saya de Malha Bank ; u (1), Farquhar ; mm (1), Amirante Group.

\section{Atlanta inflata Souleyet.}

Stat. n (132), N. of N. Saya de Malha Bank.

* On the anatomy and classification of the Heteropoda, Trans. Roy. Soc. Edinb. vol. xxiii. 1862. The figure here referred to has been copied by me (Die Heteropoden der Siboga-Expedition, Siboga-Expeditie, Monogr. li. Leiden, 1906, Pl. vil. fig. 5.

$\dagger$ Especially to: Systematic monograph of the Atlantidæ, etc., Notes Leyden Museum, vol. xxx. pp. 6, 7 .

$\ddagger$ l.c. p. 3 . 
6. Atlanta helicinoides Souleyet.

Stat. u (1), Farquhar.

7. Atlanta turriculata d'Orbigny.

Stat. P (1), Chagos Archipelago.

8. Atlanta inclinata Souleyet.

Stat. N (1), Chagos Archipelago ; q (2), u (3), Farquhar ; nn (2), Amirante Group.

9. Atlanta gibbosa Souleyet.

Stat. u (2), Farquhar.

\section{Carinariidæ.}

\section{Carinaria Lamarck.}

\section{Carinaria sp.}

"Investigator" specimens : $12^{\circ} 20^{\prime}$ N., $85^{\circ} 8^{\prime}$ E., 1803 fms, one small broken shell; 7 miles S.E. by E. of Ross Island, $265 \mathrm{fms}, 1 \mathrm{sp}$.

This last specimen, of a length of about $30 \mathrm{~mm}$., had lost nearly all its shell, only a few broken fragments adhering to the visceral nucleus, which itself was greatly damaged; the actual form of the shell could not be made out. The animal was preserved in weak alcohol and was consequently very liable to damage by any manipulation. It showed a huge proboscis and a small rounded fin with a sucker at the usual place in Carinaria, viz. at the distal margin, near the base. The eyes had the general shape of those of Pterotrachea s.s., a character not previously, so far as I know, met with in Carinaria, the left eye exhibited a small tentacle at the inner side. The visceral nucleus, or rather its remnants, was highly elevated.

The shell from the other locality showed in the form and disposition of the spire some resemblance to C. cithara Benson, recorded from the Indian Ocean, but it could not be determined with certainty.

\section{Pterosoma Lesson.}

I take this opportunity of rectifying some mistakes in my former notes about the history of this genus*, the literature of which I had no opportunity of studying at that time.

The genus was established by Lesson $\uparrow$ and a few years later redescribed by the same author $\ddagger$ in a manner which clearly shows his opinion about its affinity to Pterotrachea, as is proved by the following passage: "un animal fort remarquable, très voisin des firoles§." The damaged condition of his specimens did not enable Lesson to give an accurate description and reliable figures, so it is not at all astonishing that only about forty

* Die Heteropoden der Siboga-Expedition, Siboga-Expeditie, Monogr. li. 1906, p. 21.

† Mêm. de la Soc. d'Hist. Nat. de Paris, t. 3, p. 414, Pl. x. fig. A, 1827.

‡ Voyage autour du monde de la "Coquille," Zool. par M. Lesson, T. ii. pp. 254-256, Pl. iII. fig. 3, 3 bis.

$\$$ So I have been wrong (l.c.) in stating that Lesson had not recognized the true systematic affinity of Pterosoma with other Heteropods. 
years later Cuthbert Collingwood*, who collected some specimens of Pterosoma in the channel of Formosa and ascribed them to the same species as that of Lesson, should nevertheless have been somewhat doubtful about his determination. He did not however give any further information about his specimens, only stating that they belonged in fact to the Heteropods.

Under these circumstances it is easy to understand how Moseley fell into the error, on the suggestion of von Willemoes Suhm, of identifying Lesson's Pterosoma with a pelagic Nemertean that he was describing †. Moseley's opinion has been adopted by Fischer*. It was not before the year 1895, when Whitelegge was fortunate enough to collect some specimens, cast ashore by an easterly gale at Mavoubra Bay near Sydney, and handed over his specimens to Hedley, that the doubts about the mysterious genus Pterosoma were definitely removed.

Hedley§ showed the true nature of Pterosoma, described the general characters of the body, fin, proboscis and shell from the only intact specimen at his disposal, and gave the first figure of the radula, thus showing its affinity to the Heteropods in general. He did not express his conviction that his species and that of Lesson, Pt. plana (strictly speaking, planum, as has been rightly advanced by Crosse $\|$ ) were identical, though this seems to result from his description.

I myself $\uparrow$ lately recorded Pterosoma among the material of the Challenger Expedition and felt justified in bestowing a new name, Pt. challengeri, upon it. After further study of Hedley's figures I think, however, that no true specific difference exists, and it is for this reason that I readily give up my new species, being now convinced that it is the same as Pt. planum.

I now describe the species more accurately than former circumstances permitted me.

11. Pterosoma planum (Lesson). (Plate 13, figs. 1-5.)

Stat. kk (1), Desroches Atoll (Amirante Group). Only one specimen (§) was caught, fortunately without any injury, except to the shell.

As previous authors have mentioned, the animal is remarkable for its broad, wing-like expansions at either side of the body. These are produced by the strong development of the cutis, which is very thick on the body and beyond this forms the large wings, gradually thinning out at the margins**. The thickening of the cutis begins just at the transition between proboscis and body, before the eyes; distally from the visceral nucleus it becomes thinner, finally almost disappearing on the tail (fig. 2). Seen from above (fig. 1) the animal is broadly heart-shaped, with a small emargination between the eyes, ending

* Rambles of a Naturalist, 1868, p. 54.

+ On a young specimen of Pelagonemertes rollestoni, Ann. Mag. Nat. Hist. (4), vol. xvi. pp. 377-382, Pl. XI. 1875 .

‡ Manuel de Conchyliologie, p. 537, 1883-1887.

\$ Pterosoma Lesson claimed as a Heteropod, Proc. Malac. Soc. London, vol. i. 1895, pp. 333-335, figs. 1-4. The author was apparently not acquainted with Moseley's hypothesis, else hẹ would not have indicated Fischer's opinion as "a mere conjecture."

\| Note sur le genre Pterosoma Lesson, Journ. de Conchyliologie, vol. xliv. pp. 207-212, 1896.

ๆ l.c. pp. 22, 23, Pl. III. fig. 75 .

** According to Hedley (l.c. p. 334) the wings are not thinner at the margins. 
distally in a rather long, slender tail. The proboscis is short and stout. In the centre of the disc is placed the visceral nucleus. A side view (fig. 2) shows the fin, with rounded edges, situated somewhat more distally than the visceral nucleus; a sucker is visible at the hinder margin, near the base of the fin.

The animal measures from tip of the proboscis to end of the tail $12 \mathrm{~mm}$., the breadth of the disc is $6 \mathrm{~mm}$. Lesson* gives for the length about $80 \mathrm{~mm}$., for the breadth $40 \mathrm{~mm}$. This seems to be a quite extraordinary size, as Hedley† notes $30 \mathrm{~mm}$. and $13 \mathrm{~mm}$. respectively, the first measurement being taken from the eyes to the end of the tail. The specimen of the Challenger, which I described + , was about as long as the animal now under consideration.

The disc, as has been said above, exhibits a heart-shaped form, slightly emarginated at the anterior edge. The whole cutis, of which the dise is formed, consists of a gelatinous, but tough, wholly transparent substance, which, on microscopical examination, proves to originate from small branching cells, widely scattered within the gelatinous material, thus forming a tissue such as is found in pelagic animals, and especially in such forms as Carinaria, Pterotrachea, etc. Numerous nerve-threads and -cells are distinctly visible in the cutis. The most conspicuous feature however consists in the differently shaped opaque dots, which are distributed all over the surface of the cutis, also on the proboscis, though lying beneath the outer epithelium. These dots have already been noted by Lesson and Hedley; I myself described them in Cardiapodaई and in Carinaria macrorhynchus Tesch; here in Pterosoma they exhibit essentially the same structure, so I have thought it superfluous to figure them again. Whether these dots are glandular or not seems to be uncertain; I could never detect any efferent duct, and the constituent elements of the agglomeration have not the aspect of unicellular glands. The close resemblance, however, of these speckles with those described and figured by Vayssière\| in Carinaria pseudorugosa, called by the author "corpuscules glandulaires" and examined under a very strong magnification, pleads for a similar nature in Pterosoma. At the margins and in the middle the dots are small, very elongated and situated in a longitudinal direction, except distally from the visceral nucleus, where they are placed transversely (fig. 1). Between the two regions named above the dots assume a rounded shape and are a trifle larger. Here and there, especially on the proximal half of the disc, some few tubercles are scattered about.

The great development of the cutis and the formation of a disc, eminently adapted to a pelagic habit, renders powerful muscles superfluous. In fact the whole musculature on the body has been diminished in the extreme, and is scarcely visible through the cutis. Near the mouth, the usual muscles for moving the buccal mass and the radula are present, in the same way as in Cardiapoda ; distally, on the proboscis, and on the body within the cutis, only a very faint longitudinal musculature exists ; on the proboscis this is crossed by a few transverse fibres. On the tail there are some rather strong longitudinal muscular

* Voyage de la "Coquille," Zool. T. ii. p. 255, Pl. in. figs. 3, 3 bis.

$\dagger$ l.c. p. $333 . \quad$ †.c. p. $23 . \quad$ l.c. pp. 73, 76, Pl. x. figs. 49, 52.

|| Mollusques Hétéropodes provenant des campagnes des yachts Hirondelle et Princesse Alice, Camp. Sc. Albert I. de Monaco, Fasc. xxvi. p. 21, Pl. vi. figs. 82-84, 1904. 
bands. The fin on the other hand exhibits very clearly the two crossing systems (figs. 2, 4), generally met with in Carinaria; it is composed of two plates, slightly converging from the base of the fin towards the undermost margin. Each of these plates consists of a system of parallel, separate muscular bands, stretching vertically from the base of the fin towards the margin, and in their course gradually becoming thinner, some towards the end dividing into two tiny branches. In the proximal part of the fin these bands are directed somewhat forward. Beneath this system lies another, constituted of stronger bands, which are fewer in number than those of the first system, all running across from the base and directed distally. I have not been able to make out whether this last system is double, like the first; it seemed to me as if it was not double. These bands do not branch towards the extremity, but anastomose now and then or are forked at their origin. At the hinder margin of the fin, near the base, is placed a small sucker (fig. $4, s$ ), from the convex side of which radiate some tiny muscles.

So the whole structure is very like that of the fin in Carinaria, and in Pterosoma the same delicate network of crossing muscular bands is also a striking character of the swimming organ.

The eyes are rather large, with a broad base and the same distribution of areas devoid of pigment, as in other Carinariidæ. At the front margin of the eye, somewhat nearer to the median line, is situated a tentacle. Now it is a curious fact, that I have again to record the total absence of the right tentacle, of which no trace could be detected, while the left was clearly developed (fig. 1,t). Perhaps this is a constant character, generic or specific, as on a former occasion* a right tentacle was not found by me in this species.

The mouth is surrounded by an annular musculature, in the same manner as in Cardiapoda. Two salivary glands (fig. 1, sg), of a rather long, cylindrical shape, open into the buccal cavity dorso-laterally, and are sharply bent ventrally towards their blind endings. In the mouth itself, the two longitudinal folds situated at the dorsal roof and slightly converging distally indicate the beginning of the osophagus; the folds are toothless, as in other Carinariidæ. The radula, at either side of which a cartilaginous attachment for the radula-muscles is found, as formerly described by me $\dagger$ in Atlanta (indeed they occur in all Heteropoda), consists of 35 transverse rows, all of the usual formula 2.1.1.1.2. The plates agree in most respects with those of Carinaria and Cardiapoda; the intermediate plate has the typical crest (fig. $5 \mathrm{a}, i p)_{+}^{+}$, the first and second lateral plates (1st lp, 2nd $l p$ ) are of nearly equal length and elegantly curved, while the central plate (fig. 5, $c p$ ) exhibits the usual three cusps. In the proximal rows of the radula, these cusps of the central plate are very unequal, the middle one being by far the largest. I have figured such a plate of the 6 th row $\left(c p^{\prime}\right)$. More distally the lateral cusps of the central plate become larger, though remaining slender and perfectly straight, till in about the 27th row their ends are slightly curved outwards ( $c p$ represents the central plate of the 31 st row).

* l.c. p. 22, Pl. III. fig. 75. Moreover the same feature has been noted by me (p. 73) in Carinaria macrorhynchus. Hedley (l.c. p. 335), however, ascribes two tentacles to Pterosoma.

$\dagger$ l.c. p. 48 , Pl. vi. fig. 1 .

† This crest was not noted by Hedley (l.c. p. 335, fig. 3).

SECOND SERIES-ZOOLOGY, VOL XIV. 
The course of the intestine from the buccal mass to the visceral nucleus is the usual one (fig. 1). The rather stout œsophagus gradually widens out into an elongate swelling, which seems to act like a crop, in which food is preliminarily stored. Afterwards the intestine becomes a slender thin-walled tube, entering finally into the visceral nucleus (fig. $3, n$ ). Here it is joined by the liver, enlarges into the stomach, and leaves the visceral nucleus at the left side of the foremost portion of the last named organ, bends over to the right side and forms an anus (fig. 1, a) beneath the thickened margin of the mantle.

The visceral nucleus, composed of the liver and the gonads, exhibits an elongated shape (figs. 1-3), and is placed in the centre of the disc, in a broad, longitudinal groove of the cutis; at the posterior pole two spiral turns of the gonad, indicating the former position of the shell, are visible, at least as seen from the right side (fig. 2). As has been already mentioned the shell itself was not present in my specimen. According to Hedley's statement*, it is much like a very depressed Carinaria shell, with a small spiral portion of $2 \frac{1}{2}$ whorls, "at right angles to which extends the adult, boat-shaped shell, white, glassy, shining, most brittle, ornamented by a double, lamellar keel, running from the embryonic shell along its periphery; from keel to margin curved growth lines undulate the side of the shell." From this description it may be inferred that the shell is like that of Carinaria, though, judging after the general shape of the visceral nucleus, one would rather think that the shell must resemble that of Cardiapoda.

The nucleus is enclosed within the very thin mantle, showing at its foremost part a thickened margin (fig. 3, $m r$, fig. 1). Perpendicular to the longitudinal axis of the nucleus, a parallel row of about eight tiny gills (fig. $3, g$ ), of the same structure as in Cardiapoda, extends downwards, accompanied at the left side of the base by a much elongated osphradium $(o s)$. Dorsally to this is situated the heart (fig. 1, at, v), with the atrium turned forward towards the gills, and receiving from them the aerated blood. On examining the mantle from above, we may also, through its thin walls, detect the kidney (tig. I, $k$ ), lying proximally and close to the rectum, on the median line. Its structure is luke wise the same as in Cardiapoda, showing the same complicated structure of its walls. I could not observe the opening to the exterior, nor the renopericardial passage.

Finally we may note, at the right side of the base of the fin, the small penis (fig. $4, p$ ). As in all Heteropods, the copulating apparatus consists of two parts, (1) the penis properly so called with a very deep seminal groove, and (2) distally from this a somewhat larger accessory apparatus probably to ensure copulation, though I could not observe the glandular structure, so distinct in Carinaria, the mucous secretion of which is obviously a help in copulating.

As to the place of Pterosoma in the system, we may safely say that it is nearly related to Carinaria, as is indicated by the visceral nucleus and the shape of the shell, also by the separate muscles in the fin. It occupies a position intermediate between Carinaria and Cardiapoda, but is distinct from both genera by its broadly expanded body.

Pterosoma planum was first found, about 90 years ago, by Lesson, between the Moluccas and New Guinea, afterwards by Cuthbert Collingwood in the Channel of Formosa, by Hedley near Sydney, by the Challenger $\dagger$ on the route between the 
Admiralty Islands and Japan. By the Sealark it is now recorded from the Amirante Group *.

\section{Cardiapoda d'Orbigny.}

\section{Cardiapoda trachydermon Tesch.}

Stat. hh (1), N. of Darros Island (Amirante Group); one specimen (q) of about $30 \mathrm{~mm}$. from tip of the proboscis to end of the tail. "Investigator" specimen : $40^{\circ} 13^{\prime} \mathrm{N}$. $93^{\circ} 40^{\prime}$ E. $370-419 \mathrm{fms}$; ; one specimen (\$) with a total length of $28 \mathrm{~mm}$.

I have very little to add to my former account $\dagger$ of this species. I have found tubercles, cutaneous glands, tentacles, tail, fin, and radula quite similar to those of the Siboga specimens. The right tentacle is somewhat smaller than the left, and both are innervated by a small nerve, issuing from the top of the central ganglia, as will be described in the following species. Here I must state that my former figure of the eye of this species is not quite sufficient, as the distribution of pigment and the general shape of the eye, as it was designated by me, needs some rectification, which will be given in the figure of the next species.

I think the Carinaroida placenta Souleyet $\neq$ must be the same as this species, judging from the general shape of the body and the length $(35 \mathrm{~mm}$.), though it is almost impossible to obtain absolute certainty, without renewed investigation of the type-specimens. These were found in the tropical Atlantic and near the Sandwich Islands.

\section{Cardiapoda sublarvis Tesch. (Plate 12, figs. 4, 5.)}

Stat. y (1), Providence; mm (1), Desroches Atoll, Amirante Group. At the first station was found a + , at the second a $\hat{\delta}$, each with a total length of $13 \mathrm{~mm}$.

As I pointed out in my former paperई, this species closely resembles C. trachydermon. The general appearance is exactly the same, and the only difference consists in the total absence of tubercles on the skin, and perhaps in the three cusps of the central plate in the radula being of equal length, whereas in $C$. trachydermon the lateral ones are smaller than the median. Yet the specific distinctness of the two species may seem to be not sufficiently established, as perhaps the presence of tubercles is due to advanced age (the specimens of $C$. trachydermon measured from 30 to $35 \mathrm{~mm}$., those of $C$. sublcevis from 12 to $25 \mathrm{~mm}$.).

I hare figured (fig. 4) the eyes which are of the same general shape as in the Carinariidæ. They are rather large, much depressed, with a round lens $(l e)$ and the usual distribution of pigment in the hinder part. The retina extends along the whole distal margin of the eye, and is connected with the cerebral ganglion by a strong but short optic nerve (ne), showing elongated swellings at both ends. The eye itself is surrounded dorsally and laterally by the skin which is considerably raised, thus forming

* After the above description had been written, I became acquainted with a short note by Raff. Issel on "Aloysia phyllosoma" (Un nuovo genere di Molluschi Eteropodi, Monitore Zool. ital. Anno XVIII, No. 7, pp. 174-176); this Aloysia, as may be inferred from the description and the accompanying figure, is a young Pterosoma, as indeed the author himself communicated to me by a letter. (Note added during press.)

† l.c. p. $77, \mathrm{Pl}$. x. fig. $52, \mathrm{Pl}$. xi. figs. $53-56$.

† Voyage de la "Bonite," Zoologie, T. ii. p. 353, Pl. xvir. figs. $1-10$.

§.c. p. 78, Pl. xI. figs. $57-59$. 
a kind of large chamber, around the eye ; at the proximal margin issues the tentacle $(t)$, with a broad, membranous base, the right being again slightly smaller than the left. On the base some longitudinal muscular fibres are visible $(m t)$ and a tiny nerve $(n t)$ proceeds from the top of the cerebral ganglion and innervates the tentacle. The cerebral ganglia $(c g)$, to the under side of which the pleural ganglia are attached, are juxtaposed, longitudinally elongated, the right being very slightly larger than the left, and give rise to numerous nerves, only a few of which are shown in the figure.

The visceral nucleus (fig. 5) is compressed, elongated, showing at the ventral pole two coils which are (in the only undamaged specimen) covered by the minute, delicate shell. This shell is apparently very brittle, as I have not been able to see it, even in fragments, in my specimens. The nucleus is, except for the coils, completely enveloped in the cutis, forming here a large mantle, with an opening at the proximal side of the nucleus. I have already described* the various organs within the mantle cavity, and now restrict myself to giving a figure of the nucleus and its surrounding parts. Most conspicuous are the gills $(g)$ and, within the mantle cavity, the kidney $(k)$, the walls of which show the same structure as in Pterosoma. The osphradium, situated near the left margin of the mantle opening, outside the row of small gills, exhibits a similar elongated shape.

It may be noted here that the Cardiapoda placenta mentioned by E. A. Smith $\dagger$ from Arron Island most likely is the same as my C. sublavis, though Smith's specimen is much larger $(77 \mathrm{~mm}$.). I found this suggestion merely on the radula, investigated by meł, of the Challenger specimen, the central plate of which shows three exactly equal cusps, just as in C. sublcevis; moreover this last species may prove to be identical with C. trachydermon. The same perhaps is to be said about the Cardiapoda placenta recorded by André§ from Amboina. The only information the author gives is a figure of the radula, which shows the same character as mentioned above.

\section{Cardiapoda acuta Tesch.}

Stat. mm (1), nn (1), Desroches Atoll, Amirante Group. Two specimens, both females, one of 20 , the other of $55 \mathrm{~mm}$. length.

I have scarcely been able to discover further characteristic features of this species, formerly described by me\|. Both specimens, which seemed to be badly preserved, possessed a stout proboscis and a long, slender tail, without any appendage; this tail is longer in my specimens than the stalk carrying the visceral nucleus, around which are placed nearly 20 gills. Tubercles are found especially on the dorsal side; they give a rather rough appearance to the body. Gland-like spots of various shape are found all over the body, in the same way as in the previous species. Yet it is distinguished at first sight by its tail being devoid of appendages, and by its yellowish colour. Thus the animal, though preserved in the same fluid (formol), forms a striking contrast with the tiny, wholly transparent C. trachydermon and C. sublavis. I observed a similar difference in the Siboga specimens of Cardiapoda.

* l.c. pp. 75,76 .

† Challenger Report, lxxii. Heteropoda, p. 26, fig. 2.

$\ddagger$ l.c. p. 25 .

\$ Mollusques d'Amboine, Revue Suisse d. Zool. T. iv. p. 405, Pl. xvir. fig. 2.

|| l.c. p. 79 , Pl. xi. figs. $60-63$. 
Pterotrachea placenta Lesson* is probably the same as this species, as the author emphasizes the fact of the tail having "ni nageoire à sa pointe $\dagger$, ni chapelet à sa suite"; moreover the animal is described to be "d'aspect tuberculeux." Lesson found a specimen, of a length of $50 \mathrm{~mm}$., off the coast of New Guinea.

Notwithstanding some difference in the shape of the fin and the position of the sucker, I suppose Cardiapoda pedunculata d'Orbignył is also to be classed with the species under discussion, as no appendages at the tail have been recorded. d'Orbigny's specimens (length $30-40 \mathrm{~mm}$.) were taken in the tropical Atlantic Ocean.

\section{Pterotracheidæ.}

Pterotrachea Forskål.

Subgenus Pterotrachea s. s. Tesch.

15. Pterotrachea $(s . s$.$) sp.$

Stat. kk (1), Desroches Atoll, Amirante Group.

It is impossible for me to determine this species with any certainty, as the only specimen is a female, and so the relative size of the sucker at the fin cannot be measured.

The animal has a total length of $33 \mathrm{~mm}$., of which the proboscis measures $6 \mathrm{~mm}$., the tail $8 \mathrm{~mm}$. the maximum breadth of the fin is $5 \mathrm{~mm}$. There are no spines before the eyes. At the left side of the visceral nucleus, which is slender and pointed as in all species of this subgenus, four gills, two of which are very inconspicuous, are to be seen.

The middle plate of the radula bears a central cusp, which is rather long, pointed and very slender; at either side follow five or six shorter ones, somewhat curved inwards. On the dorsal roof of the buccal cavity two longitudinal muscular folds, leading into the œsophagus, show some chitinous teeth, five at either side, the proximal ones being very small.

I have not ventured to name this specimen, which, though beyond doubt belonging to the above named subgenus, does not exhibit any characteristic feature. To give it a name would only serve to increase the already great confusion in the nomenclature of the Pterotrachea species.

16. Pterotrachea (s. s.) microptera? Tesch.

Stat. a (1), Mauritius; k (1), Nazareth Bank.

Both specimens were females; the determination to my regret therefore cannot be regarded as quite certain. They were of nearly the same size, the first specimen of a total length of $21 \mathrm{~mm}$., the second, in which the tail and also the fin are torn away, of $23 \mathrm{~mm}$. The proboscis in both measures $6 \mathrm{~mm}$., and is slender and pointed. In the first specimen the fin is extremely small, its maximum diameter being only $2 \mathrm{~mm}$. It is mainly on account of this small fin that I have referred the specimens, which in general aspect are very much alike, to the species mentioned above. The skin is without any

* Voyage de la "Coquille," Zoologie, T. ii. p. 253, Pl. III. fig. 2.

$\dagger$ From this we may conclude that Souleyet and also E. A. Smith were wrong in identifying their species with that of Lesson.

† Voyage dans l'Amérique méridionale, T. v. p. 156, Pl. xi. fig. 5 . 
tubercles, neither are there spines before the eyes. At the left side of the very slender visceral nucleus three or four minute gills are present.

The middle plate of the radula, investigated by me in the only intact specimen, exhibits a short, broad central cusp, at either side of which extends a row of four or five smaller ones. The palatinal teeth number four in each row.

17. Pterotrachea (s.s.) scutata (Gegenbaur). (Plate 14, figs. 1-3.)

Stat. 1 (1), Nazareth Bank. Dredging station D 5 (1), Providence. Two specimens, both females, were caught, with a total length of 52 and $76 \mathrm{~mm}$. respectively.

The most remarkable character of this species is the considerable development of the cutis on the proximal half of the body (figs. 1, 2). It is true that in all intact specimens of Pterotrachea, if rightly preserved, the cutis on the first part of the body, especially at the ventral side, is somewhat thickened, leaving a kind of gular groove ventrally; here, in Pt. scutata however this character is much more accentuated. Seen from above (fig. 2) the body is much broadened out at its proximal half by the thick cutis, exhibiting at the ventral side a rather deep groove, into which the proboscis can be bent back. The whole cutis is perfectly transparent, and of a tough, semi-cartilaginous nature, as in Pterosoma. Also in other respects a comparison with this genus may be allowed as in Pt. scutata the foremost margin of the cutis projects beyond the eyes and forms a slight emargination. Distally the thick envelopment of the body is soon reduced, though it remains very tough. Everywhere spines and tubercles are found, especially on the dorsal side, where some indistinct longitudinal rows are formed (fig. 2), at either side of the gular groove, in the region of the visceral nucleus (which is surrounded, proximally and distally, by two longitudinal, minutely toothed crests), and on the tail where the lateral rows follow exactly the second and third muscular bands. There are no spinules on the proboscis nor any denticles in front of the eyes, except those on the anterior margin of the thickened cutis.

The proboscis is rather weak, measuring only $\frac{1}{5}$ of the total length of the animal. The rounded fin, without sucker in my female specimens, is situated half-way between the eyes and the visceral nucleus (fig. 1) and is very small. The visceral nucleus is elongated, slender, with about eight gills at its front and left side. The tail ends in a pair of horizontal, unusually tiny fins.

I have no doubt this species is the same as that described by Gegenbaur*, who particularly emphasizes the existence of the thickened cutis between the eyes and the region of the fin, in the following words: "der Vorderteil ist...durch eine beträchtliche, vorzüglich nach der Seite hin ausgedehnte Masse der glashellen Bindesubstanz ausgezeichnet, und unterscheidet somit diese Art leicht von den übrigen bekannten Arten. Diese Ausbreitung der Leibeshülle beginnt vorn an der Basis der Rüssels, setzt sich in sanfter Wölbung...über den Anfangsteil des Rückens fort, schlägt sich an beiden Seiten in Form starker Wülste nach unten und begrenzt dort eine vorn schmale und tief nach hinten zu sich erweiternd auslaufende Grube, in welche der Rüssel sich teilweise einlagern kann. Gegen die übrige Körperoberfläche ist diese kapuzenartige Wulstung überall scharf abgesetzt."

* Untersuchungen über Pteropoden und Heteropoden, p. 185, Pl. vin. figs. 19, 20, 1855. 
Gegenbaur notes in his specimens ten to twelve gills; I myself found no more than eight.

The rounded whitish spots with a filament in their centres, as they are generally found in Pterotrachea, and also mentioned by Gegenbaur in this species, seemed to be quite absent in my specimens, as I found no trace of them.

Recently a new species, Firola gegenbauri, has been described by Vayssière* which in my opinion is identical with Gegenbaur's species; indeed Vayssière himself, though denying the identity, alluded to the close resemblance of the two forms, on account of the cutis on the anterior part forming at either side a large lobe, hanging down from the body, without being connected to that of the opposite side; moreover toothed crests in the region of the visceral nucleus and denticles on the tail are particularly mentioned as characteristic features. The same is shown in fig. 1. It is remarkable that Vayssière notes no less than twenty-two gills.

To confirm my suggestion that Pt. scutata and Pt. gegenbauri are identical, I have prepared the radula and sought after the palatinal teeth. As to the first, I counted 30 rows (25 according to Vayssière), with the usual formula 2. 1. 1. 1. 2. All plates in a transverse row quite agreed with those represented in Vayssière's figure $\dagger$. The breadth of the central plate I found three times the length of the same; the measurements of this plate in the 5 th row are $\frac{2}{3}$ of the corresponding one in the 16 th row; on account of this exact agreement with Vayssière's statements, I have thought it superfluous to figure the radula again.

The peribuccal teeth (fig. 3) form a very remarkable character of this species ; they also have been mentioned by the French author. On the large muscular fold at the roof of the buccal cavity I noted six palatinal teeth, the proximal ones very inconspicuous (Vayssière found five such teeth at either side). The peribuccal teeth are very numerous, situated at the lips, chiefly crowded together at the dorsal and ventral halves. A single somewhat larger tooth is placed dorsally, just on the median line. On the dorsal side there are three indistinct rows; laterally the teeth are more scanty; towards the ventral half they even entirely disappear, but form on the ventral region an isolated small group. All these teeth are slender and feebly curved. Here again I must mention a difference between my observations and Vayssière's description, according to which the peribuccal teeth are most numerous dorsally and laterally. This curious armature of the buccal cavity has as yet been found only in this species and in Pt. talismani Vayssière.

Subgenus Euryops Tesch.

18. Pterotrachea (Euryops) mutabilis Tesch. (Plate 14, fig. 4.)

Stat. kk (1), Desroches Atoll, Amirante Group. A single specimen (§) with a total length of $40 \mathrm{~mm}$.

The excellent preservation induces me to give a figure, to complete my former descrip-

* Mollusques Hétéropodes de "l'Hirondelle" et de la "Princesse Alice," Résult. Camp. Scient. Albert I Ir de Monaco, Fasc. xxvi. pp. 39-42, Pl. III. figs. $45-50$.

+ Viz., his figure 50; fig. 49 represents probably a central plate of an abnormal character, as Vayssière himself also believes. 
tion*. The body is cylindrical, enveloped in a thin, but inflated cutis, forming at the throat at either side a fold, such as generally occurs in Pterotrachea. On the fold some minute spinules are to be found, the only structure of the kind in this species, as I observed none elsewhere, neither on the body, nor before the eyes. The proboscis is stout, measuring $\frac{1}{4}$ of the total length. Fin large, rounded; sucker conspicuous. Visceral nucleus inflated, short, bearing about nine gills at its proximal and left side. Tail high, owing to accidental contraction; the muscular bands and the horizontal fins do not exhibit any characters worth mention except for a row of spines on the third muscular band. In the region of the fin the characteristic circular glandular organs of Pterotrachea are scattered about; on the anterior part of the body and on the proboscis occur numerous pale spots, likewise of a glandular nature, and similar to those occurring in the Carinariidæ.

The eyes of this species have the characteristic shape on account of which I founded $\dagger$ the subgenus Euryops. They are figured very accurately by Hesset.

One of the specimens of this species in the Siboga material exhibited a few indistinct purpureous spots on the body. For this reason, and because of the lack of spines before the eyes, I think it not improbable that my species is identical with Pt. mutica Gegenbaur, Keferstein, Carus, nec Lesueur, Vayssière. The great confusion however in the nomenclature, especially of the Pterotracheidæ, does not warrant any certainty about the truth of my surmise, and a renewed and thorough review of this group of animals, notably from the Mediterranean, would be a valuable task for any naturalist.

\section{Firoloida Lesueur.}

\section{Firoloida kowalewskyi Vayssière.}

Stat. A (2), N (1), Chagos Archipelago ; a (6), c (2), Mauritius ; x (2), Providence; aa (2), bb (1), N. of Providence; dd (12), ee (1), kk (3), 11 (1), mm (2), Amirante Group.

This species was found at 12 stations, especially from the Amirante Group, with a total number of 36 specimens. It is remarkable for its distinct sexual dimorphism, pronounced (1) in the presence or absence of a sucker and of tentacles, (2) in the different form of the tail, (3) in the unequal development of the very small gills. To my former statementsई I can add that I found this last character somewhat modified, as in some female specimens the gills are very inconspicuous, or even altogether wanting.

I am much inclined to suppose all the so-called different species of Firoloida described by various authors will prove to be the same species, identical with $F$. kowalewskyi. All Firoloida specimens I have examined exhibited essentially the same features. Even $F$. desmaresti, as figured recently by Vayssière $\|$, notwithstanding the accurate description, does not differ in the main from the species now recorded from the Sealark. The male of $F$. kowalewskyi agrees in all respects with that of $F$. desmaresti, judging from Vayssière's account, except for the caudal filament, which is not always provided with

* l.c. p. 88 , Pl. xıIr. figs. $86-89$.

+ l.c. pp. 83,84 .

‡ Die Augen einiger Mollusken, Zeitschr. wiss. Zool. Bd. lxviii. 1900, Pl. xxıx. figs. 57, 58.

$\S$ l.c. pp. $90-95, \mathrm{Pl}$. xIv.

|| l.c. pp. $43-45, \mathrm{Pl}$. Iv. figs. $66-68, \mathrm{Pl}$. v. figs. $69,70,76$. 
small swellings at equal distances, but in some cases has a somewhat articulated appearance, as in the female of Vayssière's $F$. desmaresti. I would emphasize the fact that I cannot explain, in this author's figure, the curious arrangement by which the two little lobes, in which the body ends, and the caudal appendage are both inserted on the proximal part of the visceral nucleus*. This peculiarity is not alluded to in any way in the text, though it differs largely from all that is known about the tail of Firoloida. However, if any error may be assumed to be excluded and the figure is taken from a normal specimen, this character indeed is wholly different from that of $F$. kowalewskyi.

\section{LIST OF THE STATIONS, FROM WHICH HETEROPODS HAVE BEEN RECORDED.}

\section{A. Plankton Stations.}

Stat. A, May 16, 2.58-3.43 P.M. N. of Chagos Archipelago.

Surface. Firoloida kowalewskyi (2 $\delta \delta \dagger)$.

Stat. L, June 6, 8.40-9.40 P.M. Peros--Diego Garcia. 100-0 fms. Atlanta lesueuri (1).

Stat. N, June 30, 1-2.45 P.м. Peros Atoll. $600-0$ fims. Oxygyrus rangi (1), Atlanta peroni (1), Atlanta inclinata (1).

Stat. P, June 30 - July 1, 6.30 P.м.—6.30 A.м. Salomon Atoll. 10-0 fms. Atlanta peroni (3), Atlanta turriculata (1).

Stat. Q, July 4-5, 7.15 P.M. -7.15 A.м. Same position.

Surface. Firoloida kowalewskyi (1 1 ).

Stat. a, Aug. 22, 1.43-2.30 P.м. Mauritius. 25-0 fms. Pterotrachea (s.s.) sp. (1 + ), Firoloida kowalewskyi (4 우). 50-0 fms. Firoloida kowalewskyi $(2, \hat{\jmath}$,, $)$.

Stat. c, Aug. 22, 4.40-5.20 P.M. Same position. 200-0 fms. Firoloida kowalewskyi (1 1 ). 275-0 fims. Firoloida kowalewskyi ( 1 f).

Stat. k, Sept. 2, 10.30-11.20 A.м. Nazareth Bank. 300-0 fims. Pterotrachea (s.s.) sp. (1 q).

Stat. 1, Sept. 2, 11.45-12.30 A.M. Same position. 250-0 fims. Pterotrachea (s. s.) scutata (1 +).

Stat. n, Sept. 8, hour? N. of N. Saya de Malha Bank. Surface. Protatlanta souleyeti (14), Atlanta lesueuri (21), Atlanta inflata (132).

Stat. q, Sept. 27, 7 -9.30 A.M. S. by E. of Farquhar. 1000-0 fms. Atlanta peroni (2), Atlanta inclinata (2).

* l.c. fig. 67. Here Vayssière depicted the visceral nucleus, and the neighbouring parts, of the female of $F$. desmaresti.

$\dagger$ Within brackets is indicated the number of specimens caught.

SECOND SERIES-ZOOLOGY, VOL. XIV. 
Stat. u, Sept. $29-30,7$ P.м. -7 A.M. Farquhar.

Surface. Atlanta peroni (1), Atlanta lesueuri (1), Atlanta inclinata (3), Atlanta helicinoides (1), Atlanta gibbosa (2).

Stat. $\mathbf{x}$, Oct. $2-3,8$ P.M. -6 A.M. Providence.

Surface. Firoloida kowalewskyi (1 $̂$ ).

Stat. y, Oct. $4-5,8$ P.м. -6 A.м. Same position.

Surface. Cardiapoda sublavis (1 \$).

Stat. aa, Oct. 6, 11.30 A.M.-1.30 P.м. Between Providence and Alphonse. 900-0 fms. Firoloida kowalewskyi (2 우).

Stat. bb, Oct. 6, 3-3.30 P.M. Same position.

140-0 fms. Firoloida kowalewskyi? (1, head only).

Stat. dd, Oct. 7, 4-5.30 P.м. S. of Alphonse Island.

Surface. Firoloida kowalewskyi (12, 10 ㅎํ, 2 우).

Stat. ee, Oct. 7-8, 9 P.M. -6 A.м. S.E. of Alphonse Island.

Surface. Firoloida kowalewskyi (l 10 ).

Stat. hh, Oct. 12-13, 8 P.м. -6 A.м. Amirante, N. of Darros Island.

Surface. Atlanta peroni (1), Cardiapoda trachydermon (1 \&).

Stat. kk, Oct. 16, 8-9.30 A.M. Amirante, Desroches Atoll.

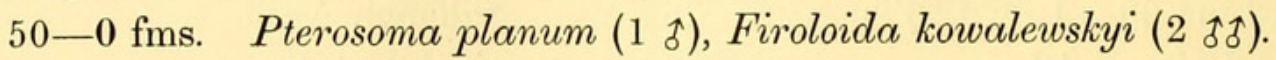

100-0 fms. Firoloida kowalewskyi (1 \%).

200-0 fms. Pterotrachea (s. s.) sp. (1 \&).

250-0 fms. Pterotrachea (Euryops) mutabilis (1 $\delta$ ).

Stat. ll, Oct. 16, morning. About same position.

750-0 fms. Firoloida kowalewskyi (1 \&).

Stat. mm, Oct. 16, about noon. About same position.

400-0 fms. Atlanta peroni (1), Atlanta lesueuri (1), Cardiapoda sublaevis (1 ઈ)), Cardiapoda acuta (1 1 ), Firoloida kowalewskyi (2 $3 \hat{\delta})$.

Stat. nn, Oct. 16, afternoon. About same position.

200-0 fms. Atlanta inclinata (2), Cardiapoda acuta (1 \&).

\section{B. Dredging Stations.}

Stat. D 5, Oct. 4, Providence, 230 fms. Dredge rectangular.

Pterotrachea (s. s.) scutata (1 +).

\section{C. “Investigator" Specimens.}

$12^{\circ} 20^{\prime}$ N., $85^{\circ} 8^{\prime}$ E., 1803 fms., Carinaria sp. (one small broken shell).

7 miles S.E. by E. of Ross Island, 265 fms., Carinaria sp. (1, beyond recognition).

(Stat. 235), $40^{\circ}\left(\right.$ ?) $13^{\prime}$ N., $93^{\circ} 40^{\prime}$ E., $370-419$ fms. ; Cardiapoda trachydermon (1 \&). 


\section{DISTRIBUTION.}

Horizontal distribution. As has been repeatedly pointed out, the Heteropods are typical inhabitants of tropical and subtropical waters. Like many other pelagic organisms they seem to extend within these regions over vast areas and some species are almost universally distributed. The occurrence of Protatlanta souleyeti in the Indian Ocean may first be mentioned; this species had been hitherto only observed in the Atlantic*. All other Atlantidæ here recorded were already known to inhabit the area explored. Among the Carinariidæ Pterosoma, which was found off the coasts of New Guinea, in the Channel of Formosa, between the Admiralty Islands and Japan, near Sydney, and in the gulf of Bengal, has been obtained by the Sealark from the western part of the Indian Ocean; further the three species of Cardiapoda of the Siboga Expedition were caught in this same region. As to the Pterotracheidæ the most noteworthy fact is the catch of Pterotrachea (s. s.) scutata, a species known to inhabit the Mediterranean (Gegenbaur, Oberwimmer) and also the eastern part of the Atlantic (Vayssière under the name Firola gegenbauri). Pterotrachea (Euryops) mutabitis has been recorded recently by the Siboga Expedition from the Malay Archipelago. Finally Firoloida kowalewskyi, which not only inhabits the seas around the Canaries and the Malay Archipelago, seems to be abundant in the tropical Indian Ocean.

It is remarkable that most of the Heteropods were found during the second part of the expedition, and especially in the Amirante Group. To what cause this must be ascribed, is difficult to say. The hydrographical conditions of the area do not seem to differ essentially from other parts of the Indian Ocean visited by the Sealark. Whether perhaps we may explain the fact by some particular method of pelagic fishing we shall now try to find out.

Vertical distribution. So far as I know, Oberwimmer was the first to impose upon the Heteropods a similar rule as had been erected by many naturalists already for the Pteropods, viz. migrations to the surface as soon as darkness begins and disappearance at daybreak $\uparrow$. According to this author both groups of organisms were most plentiful at the surface from 6.45 P.M. to 8.45 P.M., afterwards became rarer, and showed from 3.45 A.M. to 5.30 A.M. another though smaller maximum, whereas surface-fishing during the day gave only poor results.

From the foregoing list of the stations from which Heteropods have been recorded it may be inferred that the following species were caught at or near the surface down to 25 fms.

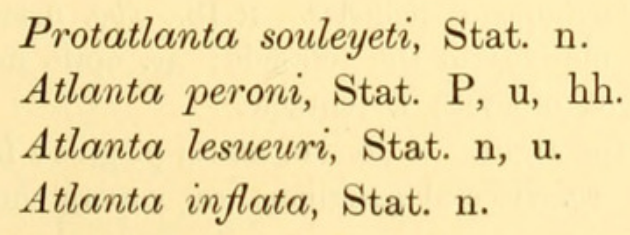

* See my recent publication: Monograph of the Atlantidæ, with description of the species in the Leyden Museum, Notes from the Leyden Museum, vol. xxx. p. 29, 1908.

$\dagger$ Heteropoden und Pteropoden, Sinusigera, gesammelt von S.M. Schiff "Pola," 1890_1894, Denkschr. Kais. Ak. Wiss. Wien, Mathem.-Naturwiss. Cl., Band 65, 1898, pp. 574, 575. 


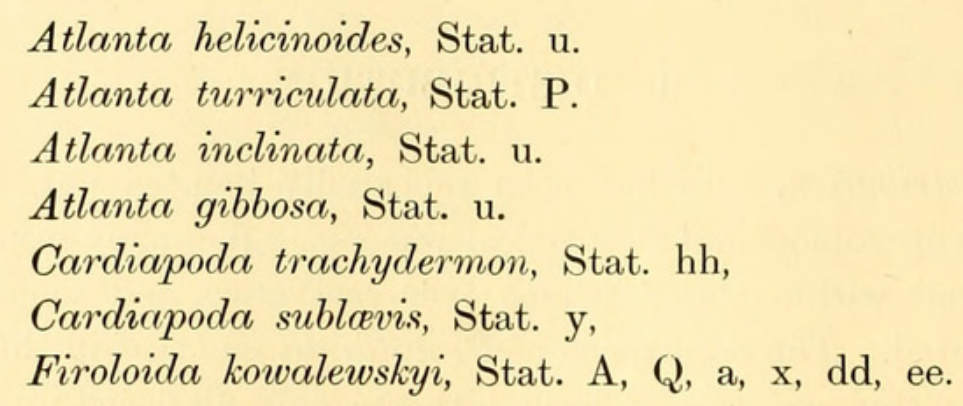

Of the stations here named, only $\mathrm{A}$, a and dd were worked during the daytime*. Firoloida kowalewskyi was the only species taken during these hours, whilst all other species were obtained exclusively at night or by heaving in the pelagic nets from a depth of 50-1000 fms. Oberwimmer's experience in the Mediterranean seems therefore to refer to a fairly general rule, according to which the Heteropods effect daily vertical migrations like the Pteropods and other pelagic organisms. It is clear, however, that we must wait for much more information before forming our conclusion. Only it may be supposed perhaps that the richer catches of Heteropods in the Amirante Group are due to a frequently employed method of pelagic fishing during many hours of the night; at least we cannot think that the waters around these islands should be richer in Heteropods than other parts of the ocean.

As to the normal depth to which the Heteropods descend we know as yet very little. The Sealark caught species of Atlanta and Firoloida if the pelagic net was sunk down to a depth of $1000-900 \mathrm{fms}$. and heaved in to the surface, but of course it is impossible to say at which depth the specimens got in the net, as no closing nets were used. Further we have some notes about the bathymetrical occurrence of Carinaria mediterranea off the coast of Ireland $\dagger$, where this species is recorded to live at depths of $768,550,450,345$ and $100 \mathrm{fms}$. The temperature in such depths of more than $700 \mathrm{fms}$. we may assume to be rather unsuitable for such typical warm-water organisms.

\section{EXPLANATION OF PLATES 12-14.}

Plate 12.

Fig. 1. Desmopterus gardineri, n. sp., from the hind side. $\times 16$.

Fig. 2. Head and part of fins of same, proximal view. $\times 25 . \quad$ Explanation of letters in figs. 1 and 2. acc.gl. accessory sexual gland; b.m. buccal mass; gon, gonad; h.gl. hinder gland; int. intestine; $m . o$. mouth opening; nephr. kidney; o.int. opening intestine; $p$. penis; st. stomach; $t$. tentacle.

Fig. 3. Oxygyrus rangi, from the left side; animal withdrawn within its shell. $\times 40$.

Fig. 4. Cerebral ganglia and eyes of Cardiapoda sublavis. $\times 18$. cbg. nerve to the buccal mass; cg. cerebral ganglion; le. lens; mt. muscles to the tentacle; ne. optic nerve; not. nerve to the otocyst; nt. nerve to the tentacle; ot. otocyst; $t$. tentacle.

Fig. 5. Visceral nucleus of same, from the right. $\times 35$. a. anus; $g$. gills; int. intestine ; $k$. kidney; $o k$. opening kidney to the exterior; $v g$. visceral ganglion; $v n$. visceral nucleus.

* Unfortunately the hour of Stat. $\mathrm{n}$ has not been recorded. Yet it would be most interesting to know it, as here a great many specimens, apparently a swarm, of Atlanta were obtained. [6-8 A.M. J. s. G.j

$\dagger$ Miss Anne L. Massy, The Pteropoda and Heteropoda of the Coasts of Ireland, Fisheries, Ireland, Sc. Invest. 1907, ii. (1909), pp. 50, 51. 


\section{Plate 13.}

Fig. 1. Pterosoma planum, seen from above. $\times 12$. a. anus; at. atrium of the heart; $e$. eye; $k$. kidney; $s g$. salivary gland; $t$. tentacle; $v$. ventricle of the heart; $v n$. visceral nucleus.

Fig. 2. The same, seen from the right side. $\times 12$.

Fig. 3. Visceral nucleus of the same, seen from the left. $\times 24$. at. atrium of the heart; g. gills; int. intestine; $m r$. thickened margin of mantle; $n$. visceral nucleus; os. osphradium.

Fig. 4. Fin and its neighbourhood, from the right. $\times 30 . f$. fin; $p$. penis; $s$. sucker.

Figs. 5,5 a. Transverse row (31st) of radula of same. $\times 320$. Fig. 5 central plate; fig. 5 a intermediate and lateral plates. $c p$. central plate; $c p^{\prime}$. central plate of 6 th row ; $i p$. intermediate plate; 1st $l p$. 2nd $l p$. first and second lateral plate.

\section{Plate 14}

Fig. 1. Pterotrachea scutata, from the left. $\times 3$.

Fig. 2. Head and proximal part of trunk of same, another specimen, from above. $\times 3 \frac{1}{2}$.

Fig. 3. Mouth of same, from within, cut open ventrally, and spread out to show the peribuccal teeth. $\times 20 . \quad d g$. dorsal group of peribuccal teeth; $l g$. lateral group; $v g$. ventral group.

Fig. 4. Pterotrachea (Euryops) mutabilis, from the right side. $\times 4$. at. atrium of the heart $k$. kidney; ok. opening kidney to the exterior; $v$. ventricle of the heart. 

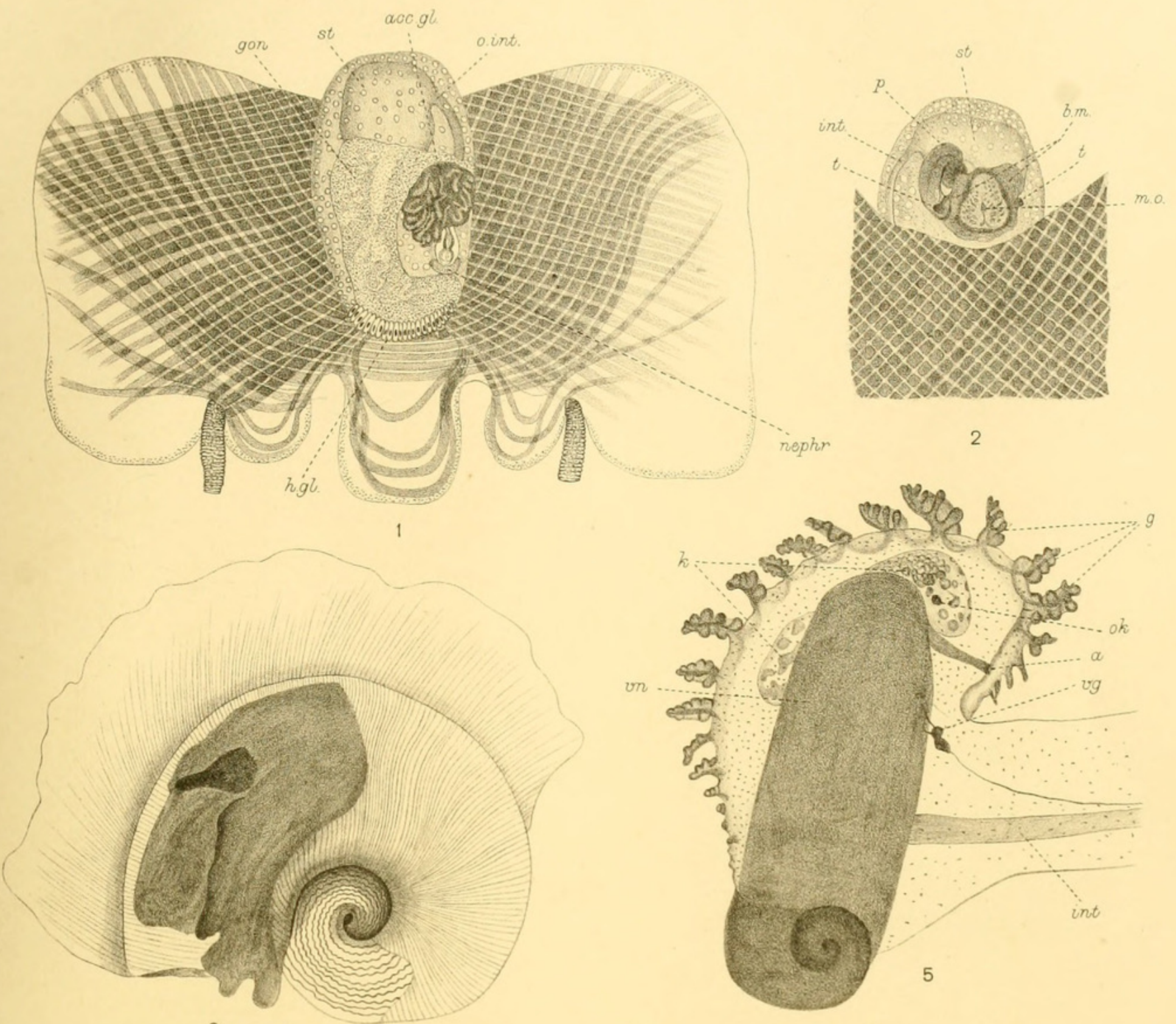

3

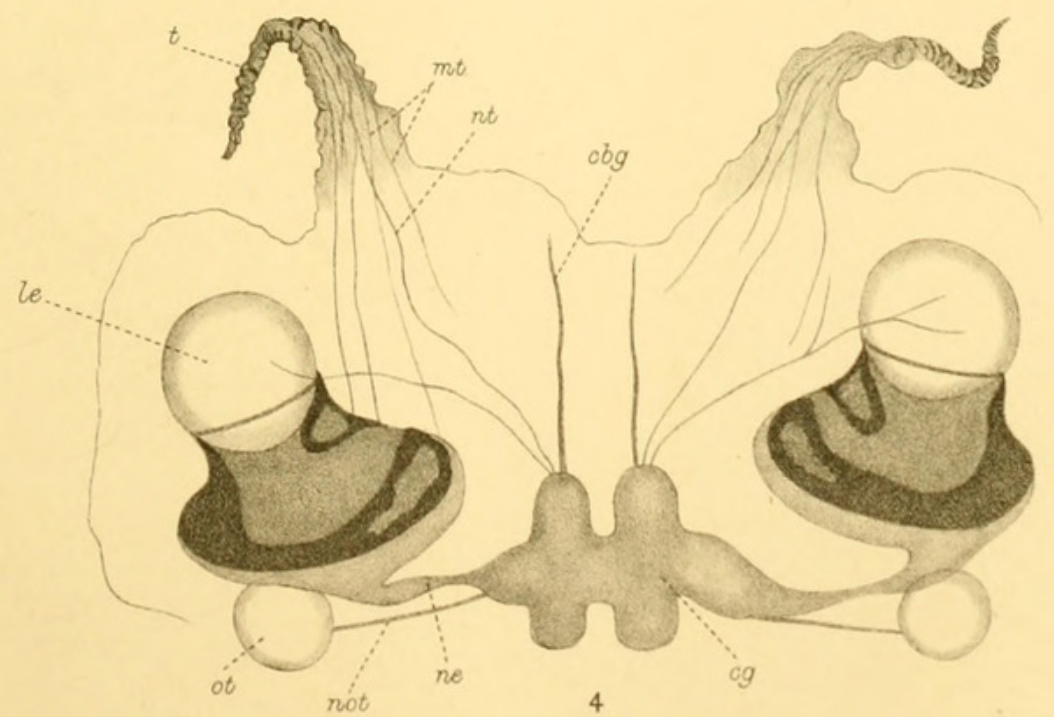

J. J Tesoh, del. 

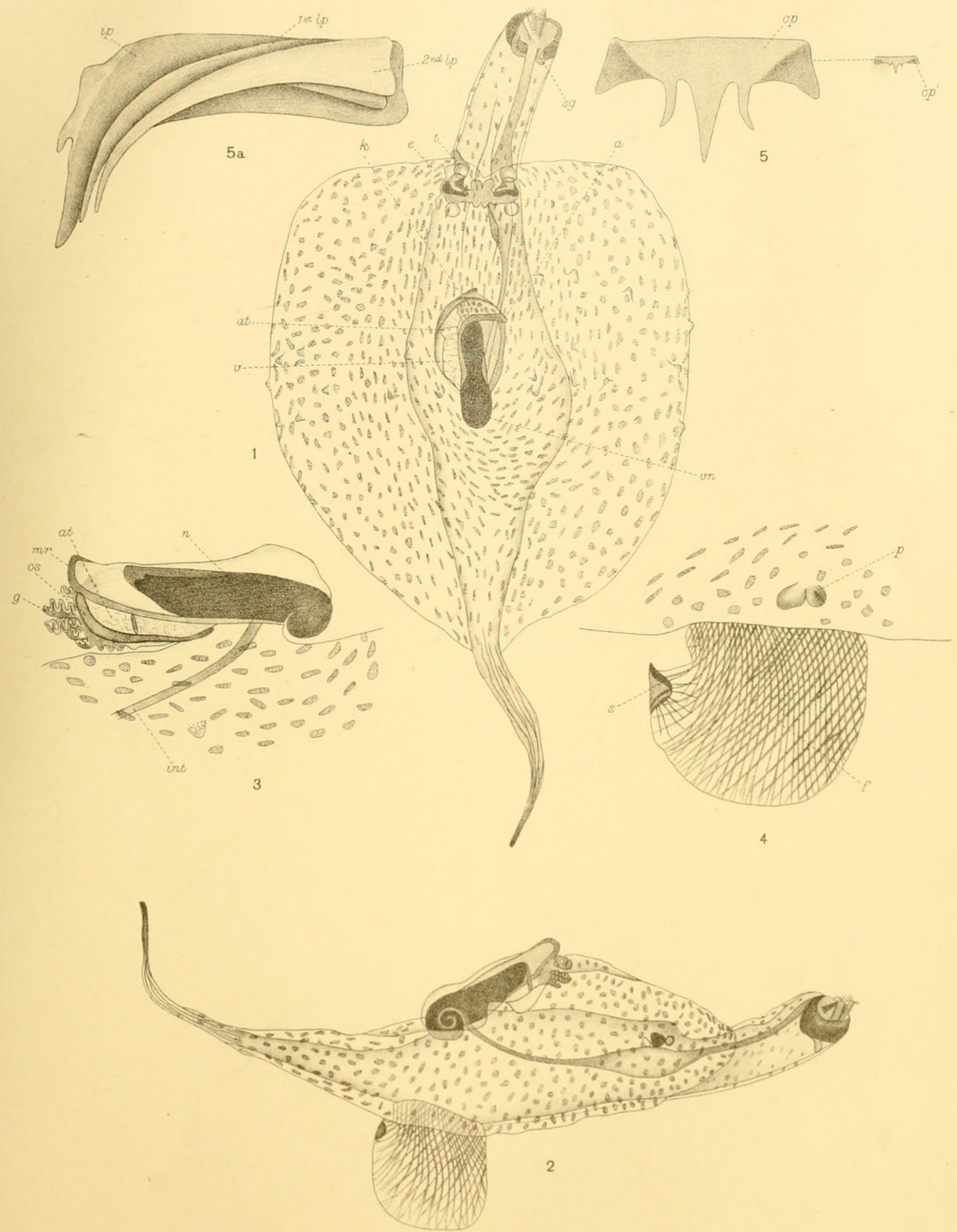


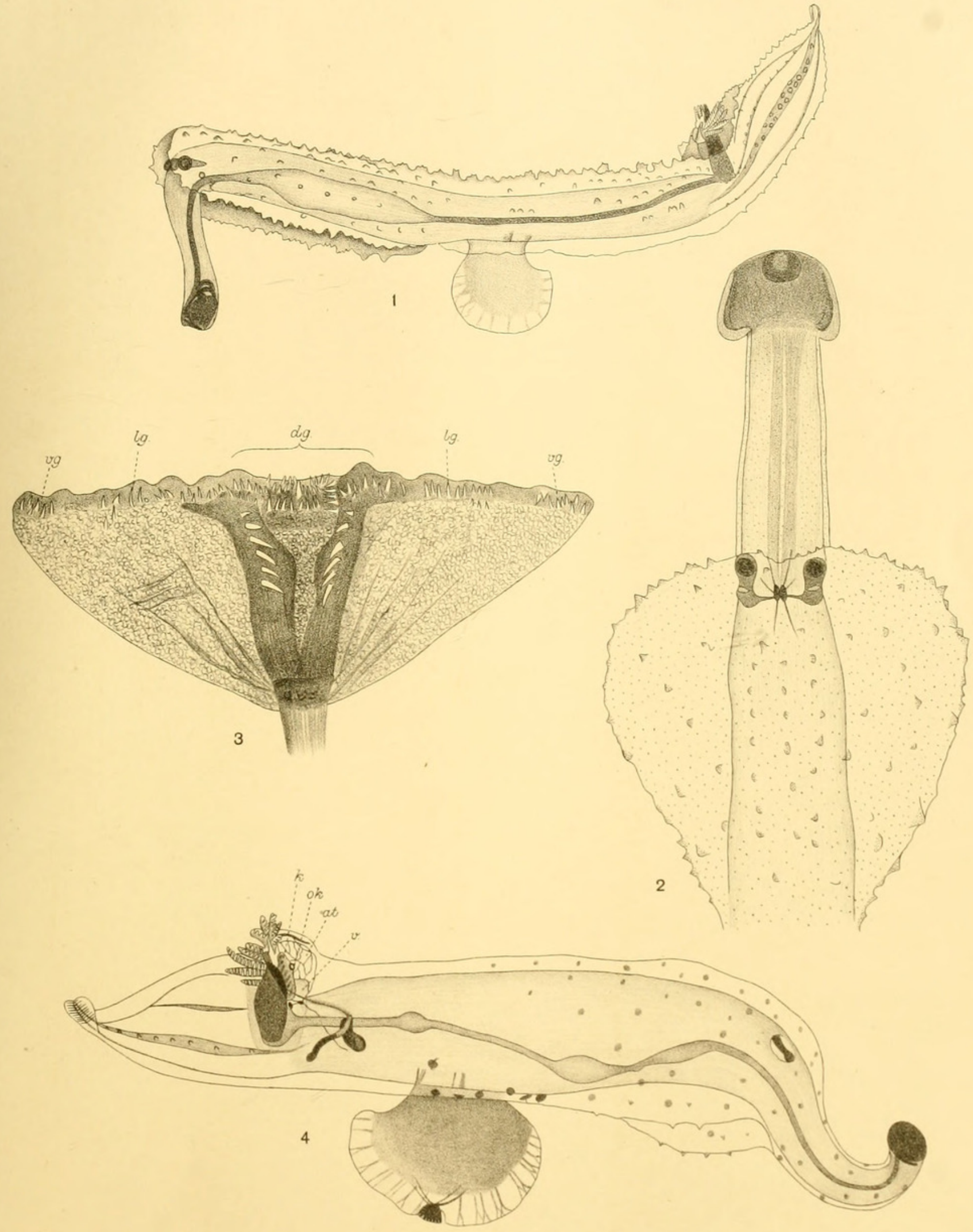




\section{$2 \mathrm{BHL}$ Biodiversity Heritage Library}

Tesch, J. J. 1910. "No. X.-PTEROPODA AND HETEROPODA." Transactions of the Linnean Society of London 14, 165-189.

https://doi.org/10.1111/j.1096-3642.1910.tb00529.x.

View This Item Online: https://www.biodiversitylibrary.org/item/55334

DOI: https://doi.org/10.1111/j.1096-3642.1910.tb00529.x

Permalink: https://www.biodiversitylibrary.org/partpdf/118986

\section{Holding Institution}

MBLWHOI Library

\section{Sponsored by}

Biodiversity Heritage Library

\section{Copyright \& Reuse}

Copyright Status: NOT IN COPYRIGHT

This document was created from content at the Biodiversity Heritage Library, the world's largest open access digital library for biodiversity literature and archives. Visit BHL at https://www.biodiversitylibrary.org. 